\title{
Antibiotic may be effective against osteoporosis
}

Preliminary research by US government scientists suggests that a common antibiotic may be as effective as estrogen in preventing the devastating bone loss caused by osterporosis. Minocycline, a derivative of tetracycline, not only appears to forestall bone loss, but cam also build bone deysity, at least in rats whose ovaries aresurgigally removed. This work, publisthedin the December 1996 issue of the jetrnal Boyo, has helped prompt the USNational Jnstitutes of Health to provide inframual funding for a clinical human trial w th the drug, which began in January. However, even if this discovery proyes to be widely effective, the fact that the minosycline is already a generic drug may keeptr frorp being widely developed for this new indicaton.

In the Bone study, led by C.T. Liang at the National Institufe on Aging in Baltimore, Maryland, byarietomized rats (and "sham surgical coutrols) were treated with either minocycligre or strogen, or a combination of both (rats do not undergo menopause, the single/grearest contributor to osteoponosis and low6one mass in women, so hormonal changes have to be induced by ovariectomiess. The researchers measured the ani- mals' bone mineral density, and repeated the procedure eight weeks later. Rats without ovaries or treatment lost an average of 15 percent of their bone mass, but rats taking the antibiotic showed little or no effect on their bone mineral density. According to Liang, "minocycline prevented that 15 percent loss."

Although it is unclear why minocycline has this effect, Liang speculates that because the antibiotic is also an anticollagenase, its beneficial effect on bone was linked to its interaction with that enzyme. Collagenase destroys collagen, a protein which attaches to the top layer of trabecular, or surface, bone, and prevents osteoclasts from eroding the material. Checking the synthesis of collagenase could create stronger defenses against the bone-chewing cells. Liang also suggests that the antibiotic increases new bone formation by affecting the generation of osteoblasts, cells that manufacture new bone tissue, but admits that the mechanism for this isn't clear either.

The potential addition of minocycline to the current limited arsenal of anti-osteoporosis medications adds an interesting wrinkle to the treatment of the disease, which affects an estimated 20 million American women, as well as millions of men. Merck and Co., Inc. made a huge splash in 1995 when the US Food and Drug Administration approved Fosamax, which was shown to reduce new spinal fractures in postmenopausal women by nearly fifty percent. More than a million American women are now taking the drug, which is being marketed as an alternative to hormone replacement therapy and other remedies. But where Fosamax treatment costs about US\$50 a month, antibiotic therapy would probably run about half as much, roughly equivalent to the cost of estrogen therapy.

But there may be a catch. Minocycline is a generic drug, so it is hard to imagine many companies investing the millions necessary to promote it to doctors and the public (a function not in the NIH's bailiwick). And although minocycline will certainly win notice from the medical community if it succeeds in clinical trials, it seems destined for a subordinate place in the market unless some pharmaceutical firm patents a new derivative of the drug.

AdAM MarCuS Baltimore, Maryland

\section{Indian high court defines medical turf}

Medical practitioners in India fear that a recent judgment handed down by the country's supreme court will halt research in traditional medicines in addition to adversely affecting the country's health care system, especially in the villages where 80 percent of the population lives. The high court has declared that doctors trained in one system of medicine cannot prescribe drugs belonging to another system in which they are unqualified. Those who do write "cross-system" prescriptions will be treated as quacks, and are liable to punishment.

This ruling is expected to have major ramifications on health care in a country where traditional and modern systems of medicine have peacefully coexisted for decades. India has over 80,000 registered practitioners. Thirty percent of these are trained in modern medicine (allopathy), and the remaining 70 percent in ayurveda, homeopathy, unani, siddha, and so forth - the so-called "Indian System of Medicine".

Until the court's ruling, practitioners of either system enjoyed a certain degree of flexibility - ayurvedic doctors prescribing harm- less but effective allopathic drugs if necessary, and allopaths using proven herbal or other traditional cures for diseases that do not respond to western medicine. But the judgment banning cross-prescriptions has scared the entire medical community, putting doctors on the defensive. For example, the Bombay (now Mumbai) branch of the Indian Medical Association, in a circular, has asked its members to stop prescribing herbal medicines to avoid "problems with civil and consumer courts," even though most traditional medicines are available over the counter.

According to C.K. Katiyar, secretary of the Ayurvedic Drug Manufacturers Association (ADMA), the court verdict has destroyed the vibrant therapeutic pluralism in the country by "dividing health-care into completely isolated watertight compartments." Katiyar warns that research in the traditional system will come to a standstill after the court verdict, because established medical institutes "are refusing to conduct clinical trials using ayurvedic medicines."

The verdict resulted from an appeal filed by a widow who alleged that her husband died because he was treated with modern medicines by a homeopath who had no formal training in allopathy. The high court upheld the appeal, and imposed a fine of Rs 300,000 (US\$8,570) for "medical negligence."

Although the court's aim was to stop abuse of modern medicines by unqualified doctors, there is fear that the blanket ban on cross-prescription will adversely affect the health care system, especially in villages. Although those trained in western medicine cater mostly to 20 per cent of the population in urban centers, India's 600,000 villages are served primarily by doctors with degrees in traditional system. "If the judgment is implemented in its letter and spirit, 80 per cent of India's population is going to be deprived of whatever health care they are getting now," says Katiyar.

The ADMA says it is preparing to file a writ petition in the supreme court challenging its verdict. According to Katiyar, twenty public interest litigations seeking revocation of the ruling may also be filed by voluntary groups in the next few weeks.

K.S. JAYARAMAN New Delhi, India 